\title{
Meningkatkan Kebugaran Jasmani Anak pada Masa Pandemi melalui Kegiatan Senam Berbasis Windows Movie Maker
}

\author{
Nurwahidin Hakim1, Wahyuni Ulpi² ${ }^{2}$ Fanny Aulia Hasyim². \\ Pendidikan Jasmani, Universitas Muhammadiyah Palopo, Indonesia(1); Pendidikan Guru \\ Pendidikan Anak Usia Dini, Universitas Muhammadiyah Palopo, Indonesia(2) \\ DOI: 10.31004/obsesi.v6i3.1954
}

\begin{abstract}
Abstrak
Permasalahan penelitian ini Bagaimana meningkatkan kebugaran jasmani anak pada masa pandemi melalui kegiatan senam berbasis windows movie maker ?. Penelitian ini bertujuan sebagai informasi baru berupa referensi ilmiah yang diperoleh dari hasil penelitian yang akan menjadi pengaplikasian guru dan orang tua di rumah sebagai bahan pembelajaran pada proses menjaga kebugaran jasmani anak melalui kegiatan senam. Desain penelitian pada penelitian ini yaitu perencanaan, Pelaksanaan, Observasi dan Refleksi. Hasil Penelitian kegiatan pra siklus nilai rata-rata yang didapatkan anak $18.33 \%$ pada kategori BB, nilai ratarata siklus I yang didapatkan anak $25 \%$ kategori $\mathrm{BB}$, nilai rata-rata siklus II yang didapatkan anak 29,2 \% kategori Berkembang MB, dan nilai rata-rata siklus III yang didapatkan anak $83,3 \%$ dengan kategori BSB.
\end{abstract}

Kata Kunci: kebugaran jasmani; pandemic; senam; movie maker

\begin{abstract}
The problem statement in this study is how to improve children's physical fitness during the pandemic through gymnastics activities based on windows movie maker. This study aims to be a new source of information in the form of scientific references obtained from research results which will later become the application of teachers and parents at home as learning materials in order to maintain children's physical fitness through gymnastics activities based on windows movie maker. The research design in this study consists of planning, implementation, observation and reflection. The results of the research on pre-cycle activities the average value obtained by children is $18.33 \%$ in the Undeveloped category the average result of the first cycle obtained by children is $25 \%$ in the Undeveloped category. The average result of the second cycle is $29.2 \%$ in the developing category And the average result of the third cycle obtained by children is $83.3 \%$ in the well-developed category
\end{abstract}

Keywords: physical fitness; pandemic; gymnastics; movie maker

Copyright (c) 2022 Nurwahidin Hakim, et al.

$\triangle$ Corresponding author:

Email Address : nurwahidinhakin@umpalopo.ac.id (Palopo, Indonesia)

Received 16 August 2021, Accepted tanggal 13 December 2021, Published 26 January 2022 


\section{PENDAHULUAN}

Wabah yang sangat berbahaya telah melanda seluruh negara tidak terkecuali negara Indonesia juga ikut terkena, sehingga program stay at home telah diterapkan begitupula dengan proses belajar mengajar disekolah dilakukan dirumah, dengan kata lain belajar daring.Hal ini dilakukan untuk mencegah perluasan COVID-19 yang sangat berbahaya (Wardani \& Ayriza, 2020). Pembelajaran daring yang ditetapkan pemerintah, ditujukan kepada seluruh jenjang pendidikan dari TK hingga perguruan tinggi. Dipilihnya alternatif ini dikarenakan berkembangnya revolusi industri 4.0. Berkembangnya revolusi industri sangat mendukung terlaksananya pembelajaran daring dari rumah Situasi yang terjadi sekarang ini, justru akan menuntut keterlibatan orang tua secara lebih maksimal dan melakukan komunikasi yang lebih intens dengan guru dalam melaporkan perkembangan anaknya.

Dalam hal ini proses belajar mengajar di kelas yang dulunya dilakukan di sekolah harus disetting sedemikian rupa sehingga bisa dilakukan dirumah. Sehingga menuntut guru untuk melakukan proses pembelajaran yang menarik. Salah satu yang dapat dilakukan yaitu membuat video kegiatan senam yang dirancang pada salah satu inovasi dalam penggunaan media pembelajaran adalah dengan menggunakan program aplikasi komputer windows movie maker.

Peneliti memilih topik meningkatkan kebugaran jasmani anak pada masa pandemi melalui kegiatan senam berbasis windows movie maker karena salah satu aplikasi yang menarik dengan menyediakan fitur yang mendukung hal yang dibutuhkan ,mengingat bahwa masa pandemi adalah masa penting untuk menjaga tubuh anak tetap sehat dan beraktivitas, menjaga imun tubuh serta mencegah terpaparnya virus COVID-19 dalam hal anak-anak dapat melakukan kegiatan senam dengan mengikuti gerakan melalui video.

Anak usia dini adalah anak yang berada pada rentang usia 0-6 tahun. Pada usia tersebut, perkembangan terjadi sangat pesat (Khaironi, 2018). Berdasarkan hasil penelitian, sekitar $40 \%$ dari perkembangan manusia terjadi pada usia dini. Oleh karena itu, usia dini dipandang sangat penting sehingga diistilahkan usia emas (golden age). Setiap individu mengalami usia dini, hanya saja usia dini tersebut hanya terjadi satu kali dalam fase kehidupan setiap manusia, sehingga keberadaan usia dini tidak boleh disia-siakan. Usia dini adalah masa yang paling tepat untuk menstimulasi perkembangan individu. Agar dapat memberikan berbagai upaya pengembangan, maka perlu diketahui tentang perkembanganperkembangan yang terjadi pada anak usia dini. Salah satu perkembangan yang penting yaitu meningkatakan kebugaran jasmani anak usia dini.

Anak belajar bergerak melalui aktivitas fisik yaitu semua gerakan tubuh yang dihasilkan oleh sistem otot yang meningkatkan pengeluaran energi diatas tuntutan fisiologis yang normal (Prasepty, 2017). Aktivitas olahraga sangat mempengaruhi kebugaran jasmani seseorang, terlebih lagi memang aktivitas itu memberikan kontribusilangsung pada komponen kebugaran jasmani. Aktivitas olahraga tetap harus disesuaikan dengan usia seseorang, misalnya jenis aktivitas, faktor keselamatan dan peralatan yang digunakan. Aktivitas olahraga tidak bisa dilakukan sembarangan,tetap harus dilakukan dengan teknik dan aturan yang benar. Walaupun senang terhadap olahraga, tetap harus melihat usia dan kondisi fisik sehingga tetap terkontrol dengan baik (Paryanto \& Wati, 2013), oleh setiap orang. Pandemi ini menjadi salah satu hal yang di khawatirkan oleh masyarakat, namun bisa dicegah dengan berbagai hal (Larasati et al., 2020). Perkembangan yang menakjubkan tersebut mencakup perkembangan fisik dan psikis (Ulpi et al., 2021). Dari segi fisik anak mengalami perkembangan yang sangat luar biasa mulai dari pertumbuhan selsel otak dan organ tubuh lainnya sehingga perkembangan kemampuan motoric kasar seperti berjalan, berlari, melompat, memanjat dan sebainya. Kemempuan lokomotor berpengaruh pada aktivitas fisik yang dilakukan oleh anak (Respati et al., 2018)

Kebugaran jasmani orang akan dapat tampil lebih dinamis/semangat dan terciptaproduktivitas kerja. Manfaat kebugaran jasmani pada saat ini sudah sangat disadari oleh masyarakat, terbukti dengan berkembangnya pusat-pusat kebugaran dan kegiatan 
olahraga yang marak diselenggarakan, hal tersebut semuanya berpangkal pada pencarian kebugaran jasmani. Namun dalam hal ini kebugaran jasmani yang dimaksud yaitu menjaga kebugaran jasmani anak usia dini pada masa pandemi.

Senam merupakan kegiatan menggerakan seluruh anggota badan dengan teknik dan gerkana yang tepat (Lestariningrum, 2019). Senam merupakan aktivitas fisik yang sesuai dalam pengembangkan kualitas fisikmotorik dan kualitas segi fisik anak secara bersamaan, Senam memiliki unsur gerakan lokomotor yang unsurnya mampu melatih konsep kekuatan tubuh, kecepatan gerak, power, daya tahan fisik, kelincahan, serta keseimbangan anak (Aguss, 2021). Kegiatan senam membantu dalam meningkatkan kebugaran jasmani anak karena gerakan-gerakan badan yang membantu proses metabolisme dalam tubuh. Dihubungkan dalam gerak nonlokomotor kegiatan senam memiliki unsur meningkatkan aspek kekuatan, kelenturan serta keseimbangan yang statis. Dihubungkan dengan gerak manipulatif senam mampu merangsang kemampuan koordinasi serta pengolahan rangsang pada pusat kesadaran anak. Kegiatan senam merupakan salah satu kegiatan berolahraga yang dapat menjaga imun tubuh tetap kuat dan sehat. Hal ini sangat bagus dilakukan oleh anak sehingga daya imun tubuh tetap terjaga dan tidak mudah terpapar COVID-19. Gerakan senam yang dilakukan akan diikuti oleh anak disekolah maupun dirumah. Mengingat pentingnya menjaga kebugaran jasmani sehingga kegiatan senam sangat bermanfaat untuk dilakukan.

Windows movie maker merupakan software yang menyediakan fitur-fitur lengkap untuk mendesain video pembelajaran sesuai dengan konten ajar yang akan disampaikan oleh para pendidik (Pratama \& Rahaningsih, 2020). Dalam hal ini peneliti akan membuat video senam dengan windows movie maker. Windows Movie Maker adalah perangkat lunak yang merupakan bagian dari Windows Essentials 2012. Fungsi utama program ini adalah untuk melakukan olah digital terhadap cuplikan-cuplikan gambar bergerak (film), misalnya untuk menambahkan animasi, efek visual ataupun sebuah redaksi singkat yang berhubungan dengan film yang sedang disunting. Windows Movie Maker adalah salah satu aplikasi editing video yang dibuat oleh Windows. Aplikasi ini diciptakan untuk memudahkan pengguna melakukan editing untuk pembuatan video ataupun film. Cara kerja aplikasi ini adalah menggabungkan video atau foto untuk dirangkai menjadi sebuah video. Tidak hanya merangkai, Windows Movie Maker juga dilengkapi dengan fitur-fitur tambahan seperti penambahan efek, transisi video, penambahan tulisan dalam video, dan lain sebagainya. Menurut Hidayati \& Nurjanah (2017) mendefinisikan Windows Movie Maker adalah sebuah program editing yang sederhana dan di desain secara menarik yang mampu menggabungkan video, gambar, musik, animasi, dan teks.

Penggunaan windows movie maker pada pembuatan video senam efektif untuk meningkatkan kebugaran jasmani anak karena anak akan tertarik melakukan senam jika mengikuti gerakan yang baru melalui video. Movie maker adalah salah satu aplikasi untuk membuat sebuah video yang menarik untuk anak usia dini. Hasil penelitian Samantha \& Almalik (2019) menunjukkan bahwa kebugaran jasmani anak dipengaruhi oleh peran orang tua serta sarana dan prasarana yang tersedia sehingga membantu dalam proses meningkatkan kebugaran jasmani anak. Pada masa pandemi tentunya membutuhkan satrategi untuk meningkatkan kebugaran jasmani anak salah satu yang bisa dilakukan dengan melakukan kegiatan senam berbasis Windows Movie Maker. Penelitian Ardiyanto et al. (2020) dengan penerapan budaya pola hidup bersih dan sehat untuk menjaga kebugaran jasmani harus menjadi kebiasaan utama di lingkungan rumah tangga. Rumah tangga menjadi pilar utama ketika masa pandemi ini, karena semua kegiatan sebagian besar berada di dalam rumah atau work from home. Di rumah setidaknya harus ada tempat cuci tangan dan sabun sebelum masuk ke dalam rumah. Membiasakan mandi dang anti baju setelah berpergian dari luar rumah.

Berdasarkan uraian teori dan tujuan penelitian yang ingin dicapai, maka kerangka konsep penelitian yang penulis rancang sebagaimana pada gambar 1. Terdapat empat variable dalam pada penelitian ini yaitu kebugaran jasmani, masa pandemic merupakan variable 
terikat atau sering disebut dependen dan kegiatan senam, Windows Movie Meker variable bebas atau sering disebut independen.

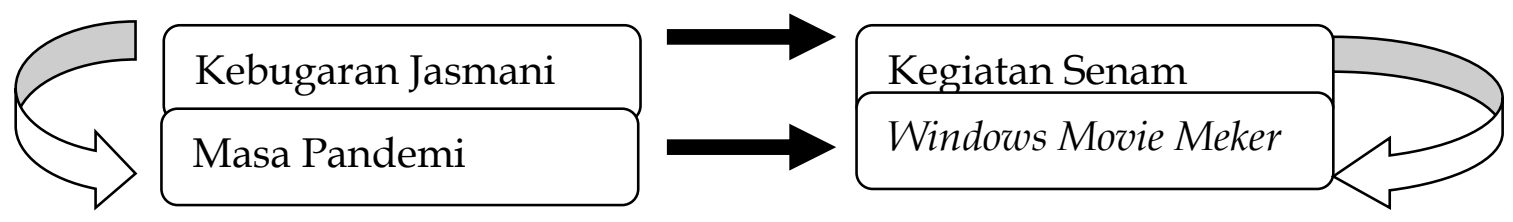

Gambar 1. Kerangka Konsep penelitian

\section{METODOLOGI}

Waktu dan tempat penelitian mengikuti ketentuan WFH (work from home) dan dipantu menggunakan aplikasi google form. Adapun desain penelitian yang akan dilakukan sebagaimana pada gambar 2 .

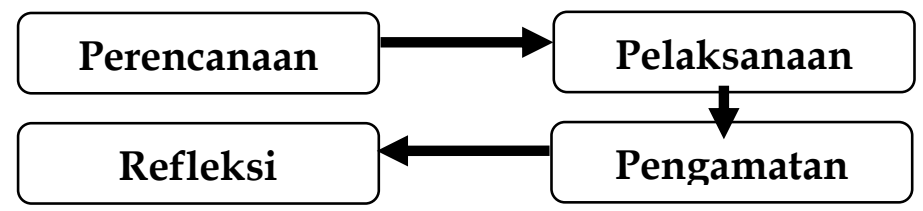

Gambar 2. Desain Penelitian

Alur ppelaksanaan penelitian ini langkah awal yang dilakukan adalah melakukan perencanaan seperti menyediakan media yang akan digunakan pada saat penelitian dan merencanakan kegiatan apa saja yang akan dilakukan, kemudian melaksanakan kegiatan senam yang videonya sudah didesain pada windows movie maker. Setelah melakukan pelaksanaan peneliti melakukan pengamatan atau observasi terkait dengan capaian anak pada saat melakukan kegiatan senam dan langkah terakhir yaitu melakukan refleksi untuk melihat kekurangan dari kegiatan serta merencanakan kegiatan untuk siklus selanjutnya.

Subjek Penelitian adalah anak usia dini yang berusia 5-6 tahun yang berdomisili di kelurahan Benteng Kota Palopo. Sedangkan variabel pada penelitian ini yaitu Kebugaran jasmani dan Masa Pandemi merupakan variable dependen dan kegiatan senam dan windows movie maker sebagai variable independen. Sehingga nantinya ada peningkatan untuk memberikan solusi terkait dengan varibael dependen.

Teknik pengumpulan data yang di gunakan dalam penelitian ini adalah sebagai berikut Observasi merupakan metode pengumpulan data untuk menilai atau mengukur perkembangan atau kemajuan anak dalam melakukan kegiatan tertentu. Pengamatan dilakukan secara langsung/daring, Dokumetasi Sebagai bukti pelaksanaan penelitian dengan cara mengambil foto saat pelaksanaan kegiatan dan mengumpulkan hasil catatan observasi dan hasil karya. Adapun instrumen penelitian yang digunakan sebagaimana pada tabel 1.

Tabel 1. kisi-kisi instrument penelitian

\begin{tabular}{|c|c|c|c|c|c|c|}
\hline \multirow[b]{2}{*}{$\mathrm{NO}$} & \multirow[b]{2}{*}{ INDIKATOR } & \multirow[b]{2}{*}{ KEGIATAN } & \multicolumn{4}{|c|}{ PENILAIAN } \\
\hline & & & $\begin{array}{c}\text { BB } \\
(25) \\
\end{array}$ & $\begin{array}{l}\text { MB } \\
(50)\end{array}$ & $\begin{array}{l}\text { BSH } \\
(75)\end{array}$ & $\begin{array}{l}\text { BSB } \\
(100)\end{array}$ \\
\hline \multirow[t]{3}{*}{1.} & \multirow{3}{*}{$\begin{array}{l}\text { Koordinasi } \\
\text { Kecepatan } \\
\text { Tangan dan Kaki }\end{array}$} & Melakukan kegiatan dasar senam & & & & \\
\hline & & $\begin{array}{l}\text { Melakukan senam } \\
\text { mengikuti video }\end{array}$ & & & & \\
\hline & & Sikap dalam melakukan senam & & & & \\
\hline
\end{tabular}


Analisis data dalam penelitian ini juga dilakukan dengan menggunakan penelitian kuantitatif. Data yang dikumpulkan pada setiap kegiatan observasi dari setiap pelaksanaan siklus dianalisis secara deskriptif kuantitatif dengan menggunakan teknik persentase untuk melihat kecenderungan yang terjadi dalam kegiatan pembelajaran. Data yang diperoleh dideskripsikan dalam bentuk narasi sehingga data mudah dipahami dan tersusun dengan baik. Selanjutnya, membuat kesimpulan berdasarkan deskripsi data, sejauh mana peningkatan kemampuan motorik halus anak yang dicapai dalam pembelajaran. Adapun rumus mean atau rerata nilai menurut (Suharsimi, 2013). Adapun indikator keberhasilan pada penelitian ini sebagaimana pada tabel 2.

Tabel 2. Indikator keberhasilan penelitian

\begin{tabular}{lll}
\hline No & \multicolumn{1}{c}{ Kriteria } & \multicolumn{1}{c}{ Skor } \\
\hline 1 & Belum Berkembang (BB) & $0 \%-25 \%$ \\
2 & Mulai Berkembang (MB) & $26 \%-50 \%$ \\
3 & Berkembang Sesuai Harapan (BSH) & $51 \%-75 \%$ \\
4 & Berkembang Sangat Baik (BSB) & $76 \%-100 \%$ \\
\hline
\end{tabular}

\section{HASIL DAN PEMBAHASAN}

Berdasarkan observasi pra siklus untuk melihat tingkat kebugaran jasmani anak pada masa pandemi COVID-19 dapat dilihat pada tabel 3. Data menunjukkan bahwa pada kegiatan melakukan kegiatan dasar senam yaitu $\mathrm{P}=\frac{850}{30} \mathrm{X} 100 \%=28.3 \%$ kemudian pada kegiatan melakukan senam dengan mengikuti video $\mathrm{P}=\frac{800}{30} \mathrm{X} 100 \%=26.6 \%$ dan pada kegiatan sikap dalam melakukan kegiatan senam $\mathrm{P}=\frac{825}{30} \times 100 \%=27.6 \%$. Sedangkan rata-rata nilai yang didapatkan anak pada indikator koordinasi kecepatan tangan dan kaki $\mathrm{P}=\frac{550}{30} \mathrm{X} 100 \%=$ $18.3 \%$.

Berdasarkan observasi siklus I untuk melihat tingkat kebugaran jasmani anak pada masa pandemi COVID-19 dapat dilihat pada tabel 4. Hasil diatas menunjukkan bahwa pada kegiatan melakukan kegiatan dasar senam yaitu $\mathrm{P}=\frac{1425}{30} \times 100 \%=47.5 \%$ kemudian pada kegiatan melakukan senam dengan mengikuti video $\mathrm{P}=\frac{1500}{30} \mathrm{X} 100 \%=50 \%$ dan pada kegiatan sikap dalam melakukan kegiatan senam $\mathrm{P}=\frac{1425}{30} \times 100 \%=47.5 \%$. Sedangkan rata-rata nilai yang didapatkan anak pada indikator koordinasi kecepatan tangan dan kaki $\mathrm{P}=\frac{750}{30} \mathrm{X} 100 \%$ $=25 \%$.Pada siklus 1 terlihat nilai yang didapatkan oleh anak masih belum sesuai dengan indikator keberhasilan yang telah ditentukan sehingga dapat pula disimpulkan bahwa kebugaran jasmani anak belum meningkat sehingga perlu ada tindakan selanjutnya yang direncanakan.

Berdasarkan observasi siklus II untuk melihat tingkat kebugaran jasmani anak pada masa pandemi COVID-19 dapat dilihat pada tabel 5. Hasil diatas menunjukkan bahwa pada kegiatan melakukan kegiatan dasar senam yaitu $\mathrm{P}=\frac{2025}{30} \mathrm{X} 100 \%=67.5 \%$ kemudian pada kegiatan melakukan senam dengan mengikuti video $\mathrm{P}=\frac{2100}{30} \mathrm{X} 100 \%=70 \%$ dan pada kegiatan sikap dalam melakukan kegiatan senam $\mathrm{P}=\frac{2100}{30} \mathrm{X} 100 \%=70 \%$. Sedangkan rata-rata nilai yang didapatkan anak pada indikator koordinasi kecepatan tangan dan kaki $\mathrm{P}=\frac{875}{30} \mathrm{X} 100 \%=29.1 \%$. Pada siklus II terlihat nilai yang didapatkan oleh anak masih belum sesuai dengan indikator keberhasilan yang telah ditentukan sehingga dapat pula disimpulkan bahwa kebugaran jasmani anak belum meningkat sehingga perlu ada tindakan selanjutnya yang direncanakan.

Berdasarkan observasi siklus III untuk melihat tingkat kebugaran jasmani anak pada masa pandemi COVID-19 dapat dilihat pada tabel 6. Hasil diatas menunjukkan bahwa pada kegiatan melakukan kegiatan dasar senam yaitu $\mathrm{P}=\frac{2956}{30} \mathrm{X} 100 \%=98.3 \%$ kemudian pada 
kegiatan melakukan senam dengan mengikuti video $\mathrm{P}=\frac{2950}{30} \times 100 \%=98.3 \%$ dan pada kegiatan sikap dalam melakukan kegiatan senam $\mathrm{P}=\frac{2975}{30} \mathrm{X} 100 \%=99.2 \%$. Sedangkan ratarata nilai yang didapatkan anak pada indikator koordinasi kecepatan tangan dan kaki $\mathrm{P}=$ $\frac{2500}{30} \times 100 \%=83.3 \%$. Pada siklus II terlihat nilai yang didapatkan oleh anak masih belum sesuai dengan indikator keberhasilan yang telah ditentukan sehingga dapat pula disimpulkan bahwa kebugaran jasmani anak belum meningkat sehingga perlu ada tindakan selanjutnya yang direncanakan.

Selanjutnya rekapitulasi perbandingan sebelum tindakan dan antar siklus dapat dilihat pada gambar 1 .

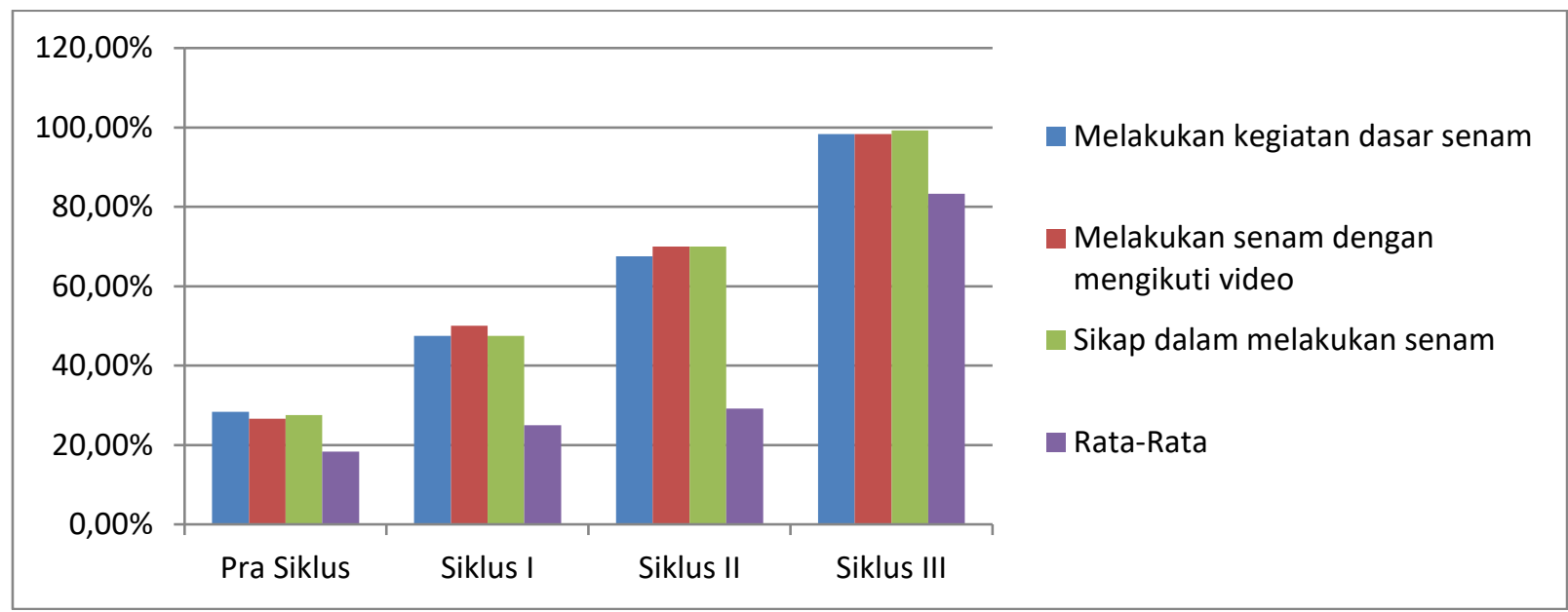

Gambar 1. Grafik Rekapitulasi Hasil Penelitian

\section{Pembahasan}

Hasil penelitian menemukan bahwa kegiatan pra siklus belum menunjukkan peningkatan kebugaran jasmani anak, sehingga dilanjutkan ke tahap siklus I namun pada siklus 1I belum meningkat dengan mencapai indikator keberhasilan, sehingga penelitian dilanjutkan sampai dengan siklus III. Pembahasan hasil penelitian dapat dilihat sebagai berikut. Sejalan dengan pendapat terkait dengan kebugaran jasmani untuk anak usia dini(Nugraha, 2015) Usia terbaik untuk melakukan stimulasi pada anak adalah sedini mungkin. Pendidikan jasmani untuk anak perlu diberikan seoptimal mungkin agar terjadi keseimbangan antara otak kanan dan kiri.

\section{Hasil Kegiatan Pra Siklus}

Menurut (Setiawan, 2018) berpendapat bahwa menjaga kebugaran sejak dini menunjang kemmapuan motorik dengan baik. Dalam tahap perncanaan peneliti menyusun rancangan sesuai dengan rencana program pembelajaran harian, mulai dari kegiatan awal, inti dan kegiatan akhir yang berkaitan dengan kegiatan senam berbasis movie maker. Peneliti menyiapkan alat dan bahan yang digunakan untuk membantu proses penelitian dengan mengalokasikan waktu yang sesuai. Kegiatan proses belajar dengan kegiatan senam berbasis movie maker dilaksanakan sebagai berikut : (1) Guru menyiapkan alat yang digunakan untuk kegiatan senam,(2) Guru menjelaskan aturan kegiatan senam, (3) Guru berperan sebagai contoh,(4)Peserta didik mengikuti gerakan senam yang dilakukan. Observasi dilakukan oleh peneliti dengan menilai indikator dan kegiatan yang telah ditetapkan, pada saat observasi peneliti menggunakan lembar observasi yang telah disiapkan. Adapun hasil observasi berdasarkan kegiatan pada pra siklus sebagaimana pada tabel 3. Pada pra siklus terlihat nilai yang didapatkan oleh anak masih belum sesuai dengan indikator keberhasilan yang telah 
ditentukan sehingga dapat pula disimpulkan bahwa kebugaran jasmani anak belum meningkat sehingga perlu ada tindakan baru.

\section{Hasil kegiatan siklus I dengan kegiatan senam berbasis movie maker}

Dalam tahap perncanaan peneliti menyusun rancangan sesuai dengan rencana program pembelajaran harian, mulai dari kegiatan awal, inti dan kegiatan akhir yang berkaitan dengan kegiatan senam berbasis movie maker. Peneliti menyiapkan alat dan bahan yang digunakan untuk membantu proses penelitian dengan mengalokasikan waktu yang sesuai. Kegiatan proses belajar dengan kegiatan senam berbasis movie maker dilaksanakan sebagai berikut : (1) Guru menyiapkan alat yang digunakan untuk kegiatan senam,(2) Guru menjelaskan aturan kegiatan senam, (3) Guru berperan sebagai contoh,(4)Peserta didik mengikuti gerakan senam yang dilakukan. Pada saat anak melakukan senam kegiatan yang dilakukan yaitu dengan mendengarkan dari speaker musik senam, kemudian anak bergerak mengikuti gerakan yang dilakukan oleh guru. Guru mendampingi anak melakukan kegiatan senam. Observasi dilakukan oleh peneliti dengan menilai indikator dan kegiatan yang telah ditetapkan, pada saat observasi peneliti menggunakan lembar observasi yang telah disiapkan.

\section{Hasil kegiatan siklus II dengan kegiatan senam berbasis movie maker}

Dalam tahap perncanaan peneliti menyusun rancangan sesuai dengan rencana program pembelajaran harian, mulai dari kegiatan awal, inti dan kegiatan akhir yang berkaitan dengan kegiatan senam berbasis movie maker. Peneliti menyiapkan alat dan bahan yang digunakan untuk membantu proses penelitian dengan mengalokasikan waktu yang sesuai. Kegiatan proses belajar dengan kegiatan senam berbasis movie maker dilaksanakan sebagai berikut (1)Guru menyiapkan alat yang digunakan untuk kegiatan senam,(2) Guru menjelaskan aturan kegiatan senam, (3) Guru berperan sebagai contoh,(4)Peserta didik mengikuti gerakan senam yang dilakukan. Pada saat anak melakukan senam kegiatan yang dilakukan yaitu guru menyiapkan LCD dan speaker untuk kegiatan senam, kemudian anak melakukan senam dengan melihat gerakan yang ada pada video, kegiatan ini diulang sebanyak 2 kali. Observasi dilakukan oleh peneliti dengan menilai indikator dan kegiatan yang telah ditetapkan, pada saat observasi peneliti menggunakan lembar observasi yang telah disiapkan. Sejalan dengan pendapat (Wicaksono, 2020) gerak sebagai acuan pencapaian dasardasar gerak yang akan mampu membekali pencapaian kemampuan gerak yang lebih komplek dimasa mendatang. Dengan demikian kemampuan pembina pendidikan jasmani dalam mengkaitkan kecerdasan majemuk dan layanan terhadap kebutuhan taksonomi gerak adalah faktor penting keberhasilan pendidikan jasmani.

\section{Hasil kegiatan siklus III dengan kegiatan senam berbasis movie maker}

Dalam tahap perncanaan peneliti menyusun rancangan sesuai dengan rencana program pembelajaran harian, mulai dari kegiatan awal, inti dan kegiatan akhir yang berkaitan dengan kegiatan senam berbasis movie maker. Peneliti menyiapkan alat dan bahan yang digunakan untuk membantu proses penelitian dengan mengalokasikan waktu yang sesuai. Kegiatan proses belajar dengan kegiatan senam berbasis movie maker dilaksanakan sebagai berikut (1)Guru menyiapkan alat yang digunakan untuk kegiatan senam,(2) Guru menjelaskan aturan kegiatan senam, (3) Guru berperan sebagai contoh,(4)Peserta didik mengikuti gerakan senam yang dilakukan. Pada saat anak melakukan senam kegiatan yang dilakukan yaitu guru menyiapkan LCD dan speaker untuk kegiatan senam, kemudian anak melakukan senam dengan melihat gerakan yang ada pada video serta guru juga ikut dalam kegiatan senam yang dilakukan. Observasi dilakukan oleh peneliti dengan menilai indikator dan kegiatan yang telah ditetapkan, pada saat observasi peneliti menggunakan lembar observasi yang telah disiapkan. (Siregar, 2011)Usia dini merupakan masa perkembangan dan pertumbuhan yang efektif berkaitan dengan motoric dalam segi kebugaran jasmani. 


\section{SIMPULAN}

Simpulan penelitian ini adalah kegiatan senam dapat meningkatkan kebugaran jasmani anak pada masa pandemi karena pada saat mealkukan kegiatan senam aktivitas fisik bergerak dan kemampuan motorik kasar anak meningkat. Selain di lembaga PAUD kegiatan senam ini juga dapat diterapkan orang tua dirumah sebagai kegiatan rutin untuk mencegah penularan covid-19 dan menjaga kebugaran jasmani anak.

\section{UCAPAN TERIMA KASIH}

Terima kasih kepada subjek dan pendidik yang telah membantu jalannya penelitian ini, terima kasih kepada Lembaga Penelitian dan Pengabdian Masyarakat Universitas Muhammadiyah Palopo yang telah membantu dari segi moril serta terima kasih kepada jurnal obsesi yang telah memberikan wadah sehingga dapat dibaca oleh khalayak khususnya untuk meningkatkan kebugaran jasmani anak pada masa pandemic melalui kegiatan senam berbasis windows Movie Maker.

\section{DAFTAR PUSTAKA}

Aguss, R. M. (2021). Kemampuan Mobilitas Gerak Anak Usia Dini 4 Sampai 5 Tahun Melalui Gerakan-Gerakan. 1(1), 58-64. https://doi.org/10.26858/tematik.v5i2.20287

Ardiyanto, A., Purnamasari, V., Sukamto, S., \& Setianingsih, E. (2020). Analisis Perilaku Hidup Bersih dan Status Kebugaran Jasmani di Era Pandemi Covid-19 Dosen PGSD. Jendela Olahraga, 5(2), 131-140. https:// doi.org/10.26877/jo.v5i2.6216

Hamzah, R. S., \& Almalik, D. (2020). Analisis Kualitas Layanan Terhadap Kepuasan Mahasiswa: Studi Kasus Pada STIE MDP Palembang. Jembatan: Jurnal Ilmiah Manajemen, 16(2), 111-120. https://doi.org/10.29259/jmbt.v16i2.9620

Hidayati, R. P. P., \& Nurjanah, S. (2017). Implementation of Project Based Learning Model with Windows Movie Maker Media in Improvement of Short Story Writing. JETL (Journal Of Education, Teaching and Learning), 164. https://doi.org/10.26737/jetl.v2i1.135

Khaironi, M. (2018). Perkembangan Anak Usia Dini. Jurnal Golden Age. https://doi.org/10.29408/goldenage.v2i01.739

Larasati, A. L., Gozali, D., \& Haribowo, C. (2020). Penggunaan Desinfektan dan Antiseptik Pada Pencegahan Penularan Covid-19 di Masyarakat. Majalah Farmasetika, 5(3). https:// doi.org/10.24198/mfarmasetika.v5i3.27066

Lestariningrum, A. (2019). Pengaruh Senam Bebek Berenang Terhadap Kemampuan Motorik Kasar Anak Usia 3-4 Tahun. Efektor, 6(1), 1-6. https:// doi.org/10.31000/ceria.v7i1.560

Nugraha, B. (2015). Pendidikan Jasmani Olahraga Usia Dini. Jurnal Pendidikan Anak, 4(1). https://doi.org/10.21831/jpa.v4i1.12344

Paryanto, R., \& Wati, I. D. P. (2013). Upaya Meningkatkan Kebugaran Jasmani Siswa Melalui Pendidikan Jasmani. Jurnal Pendidikan Dan Pembelajaran Untan, 2(5), 143-154.

Prasepty, W. (2017). Pengembangan Instrumen Tes Kebugaran Jasmani untuk Anak TK Usia 4-6 Tahun. In Journal of Physical Education and Sports (Vol. 6, Issue 2, pp. 205-210).

Pratama, F. A., \& Rahaningsih, N. (2020). Penggunaan Media Windows Movie Maker Untuk Memprediksi Pemahaman Matakuliah Akuntansi Dengan Metode Support Vector Machine. Jurnal Gerbang STMIK Bani Saleh, 1-6. https://jurnal.stmik.banisaleh.ac.id/index.php/JIST/article/view/45

Respati, R., Nur, L., \& Rahman, T. (2018). Gerak Dan Lagu Sebagai Model Stimulasi Pengembangan Kecerdasan Kinestetik Anak Usia Dini. JPUD - Jurnal Pendidikan Usia Dini, 12(2), 321-330. https://doi.org/10.21009/JPUD.122.13

Setiawan, J. (2018). Tinjauan buku. Jurnal TULOS, 16(2), 207-227. https://doi.org/10.25157/jigj.v6i2.1716 
Siregar, N. (2011). Kemampuan Guru Tk Dalam Mengajar Gerak Anak Pada Taman KanakKanak Di Matraman Jakarta -Timur Dalam Upaya Peningkatan Kebugaran Jasmani Pada Anak Usia Dini. Jurnal Olahraga Prestasi, 7(7), 11-19. https://doi.org/10.21831/jorpres.v7i7.10281

Suharsimi, A. (2013). Metodologi penelitian. Bumi Aksara, 62.

Ulpi, W., Hakim, N., Kadir, A., Pajarianto, H., \& Rahmatia, R. (2021). Gambaran Kebugaran Jasmani Anak Usia Dini pada Masa Pandemi Covid-19. Jurnal Obsesi: Jurnal Pendidikan Anak Usia Dini, 6(1), 30-39. https:// doi.org/10.31004/obsesi.v6i1.1197

Wardani, A., \& Ayriza, Y. (2020). Analisis Kendala Orang Tua dalam Mendampingi Anak Belajar di Rumah Pada Masa Pandemi Covid-19. Jurnal Obsesi : Jurnal Pendidikan Anak Usia Dini, 5(1), 772. https:// doi.org/10.31004/obsesi.v5i1.705

Wicaksono, L. (2020). Pelaksanaan Pendidikan Jasmani dan Olahraga Anak Usia Dini. Jiunal Pendidikan Anak, 274-282. 
Lampiran

Tabel 1 Hasil Kegiatan Anak Pra Siklus

\begin{tabular}{|c|c|c|c|c|c|c|c|}
\hline \multirow[t]{2}{*}{ No } & \multirow{2}{*}{$\begin{array}{l}\text { Nama } \\
\text { Anak }\end{array}$} & \multirow{2}{*}{ JK } & \multicolumn{3}{|c|}{ Koordinasi kecepatan tangan dan kaki } & \multirow[t]{2}{*}{ Total } & \multirow{2}{*}{$\begin{array}{l}\text { Nilai } \\
\text { rata-rata }\end{array}$} \\
\hline & & & $\begin{array}{c}\text { Melakukan } \\
\text { kegiatan dasar } \\
\text { senam }\end{array}$ & $\begin{array}{c}\text { Melakukan senam } \\
\text { dengan mengikuti } \\
\text { video }\end{array}$ & $\begin{array}{c}\text { Sikap dalam } \\
\text { melakukan } \\
\text { senam }\end{array}$ & & \\
\hline 1 & AM & $\mathrm{P}$ & 25 & 25 & 50 & 150 & 37.5 \\
\hline 2 & DS & $\mathrm{P}$ & 25 & 25 & 25 & 75 & 25 \\
\hline 3 & KL & $\mathrm{L}$ & 25 & 25 & 25 & 75 & 25 \\
\hline 4 & MM & $\mathrm{L}$ & 25 & 25 & 25 & 75 & 25 \\
\hline 5 & DS & $\mathrm{P}$ & 25 & 25 & 25 & 75 & 25 \\
\hline 6 & HD & $\mathrm{P}$ & 25 & 50 & 25 & 150 & 37.5 \\
\hline 7 & AZ & $\mathrm{P}$ & 50 & 25 & 25 & 150 & 37.5 \\
\hline 8 & AK & $\mathrm{L}$ & 25 & 25 & 25 & 75 & 25 \\
\hline 9 & SHN & $P$ & 25 & 25 & 25 & 75 & 25 \\
\hline 10 & AYD & $\mathrm{P}$ & 50 & 25 & 25 & 150 & 25 \\
\hline 11 & WH & $\mathrm{P}$ & 25 & 25 & 25 & 75 & 25 \\
\hline 12 & ST & $\mathrm{L}$ & 25 & 50 & 25 & 150 & 37.5 \\
\hline 13 & KU & $\mathrm{L}$ & 25 & 25 & 25 & 75 & 25 \\
\hline 14 & LK & $\mathrm{L}$ & 25 & 25 & 50 & 150 & 37.5 \\
\hline 15 & WHA & $\mathrm{L}$ & 25 & 25 & 25 & 75 & 25 \\
\hline 16 & HD & $\mathrm{P}$ & 50 & 25 & 25 & 150 & 37.5 \\
\hline 17 & SJ & $\mathrm{P}$ & 50 & 25 & 25 & 150 & 37.5 \\
\hline 18 & PI & $\mathrm{L}$ & 25 & 25 & 25 & 75 & 25 \\
\hline 19 & AL & $\mathrm{L}$ & 25 & 25 & 25 & 75 & 25 \\
\hline 20 & MH & $\mathrm{L}$ & 25 & 25 & 25 & 75 & 25 \\
\hline 21 & MP & $\mathrm{L}$ & 25 & 25 & 25 & 75 & 25 \\
\hline 22 & SK & $\mathrm{P}$ & 25 & 25 & 25 & 75 & 25 \\
\hline 23 & LL & $\mathrm{P}$ & 25 & 25 & 25 & 75 & 25 \\
\hline 24 & RS & $\mathrm{P}$ & 25 & 25 & 25 & 75 & 25 \\
\hline 25 & TU & $\mathrm{P}$ & 25 & 25 & 50 & 150 & 37.5 \\
\hline 26 & ZA & $\mathrm{P}$ & 25 & 25 & 25 & 75 & 25 \\
\hline 27 & $\mathrm{HI}$ & $\mathrm{P}$ & 25 & 25 & 25 & 75 & 25 \\
\hline 28 & GI & $\mathrm{P}$ & 25 & 25 & 25 & 75 & 25 \\
\hline 29 & PR & $\mathrm{P}$ & 25 & 25 & 25 & 75 & 25 \\
\hline 30 & WA & $\mathrm{L}$ & 25 & 25 & 25 & 75 & 25 \\
\hline & Jumlah & & $28.33 \%$ & $26,6 \%$ & $27.5 \%$ & & $18.33 \%$ \\
\hline
\end{tabular}


Tabel 2 Hasil Kegiatan Anak Siklus I

\begin{tabular}{|c|c|c|c|c|c|c|c|}
\hline \multirow[t]{2}{*}{ No } & \multirow{2}{*}{$\begin{array}{l}\text { Nama } \\
\text { Anak }\end{array}$} & \multirow[t]{2}{*}{ JK } & \multicolumn{3}{|c|}{ Koordinasi kecepatan tangan dan kaki } & \multirow[t]{2}{*}{ Total } & \multirow{2}{*}{$\begin{array}{c}\text { Nilai } \\
\text { rata-rata }\end{array}$} \\
\hline & & & $\begin{array}{l}\text { Melakukan } \\
\text { kegiatan dasar } \\
\text { senam }\end{array}$ & $\begin{array}{c}\text { Melakukan senam } \\
\text { dengan mengikuti } \\
\text { video }\end{array}$ & $\begin{array}{c}\text { Sikap dalam } \\
\text { melakukan } \\
\text { senam }\end{array}$ & & \\
\hline 1 & AM & $\mathrm{P}$ & 50 & 50 & 75 & 175 & 58.3 \\
\hline 2 & DS & $\mathrm{P}$ & 50 & 50 & 50 & 150 & 50 \\
\hline 3 & KL & $\mathrm{L}$ & 50 & 50 & 50 & 150 & 50 \\
\hline 4 & MM & $\mathrm{L}$ & 50 & 50 & 50 & 150 & 50 \\
\hline 5 & DS & $\mathrm{P}$ & 50 & 50 & 50 & 150 & 50 \\
\hline 6 & HD & $\mathrm{P}$ & 50 & 75 & 50 & 175 & 58.3 \\
\hline 7 & AZ & $\mathrm{P}$ & 75 & 50 & 50 & 175 & 58.3 \\
\hline 8 & $\mathrm{AK}$ & $\mathrm{L}$ & 50 & 25 & 50 & 125 & 41.6 \\
\hline 9 & SHN & $\mathrm{P}$ & 25 & 50 & 50 & 125 & 41.6 \\
\hline 10 & AYD & $\mathrm{P}$ & 50 & 50 & 50 & 150 & 50 \\
\hline 11 & WH & $\mathrm{P}$ & 50 & 50 & 25 & 125 & 41.6 \\
\hline 12 & ST & $\mathrm{L}$ & 50 & 75 & 50 & 175 & 58.3 \\
\hline 13 & KU & $\mathrm{L}$ & 50 & 50 & 50 & 150 & 50 \\
\hline 14 & LK & $\mathrm{L}$ & 50 & 50 & 75 & 175 & 58.3 \\
\hline 15 & WHA & $\mathrm{L}$ & 50 & 50 & 50 & 150 & 50 \\
\hline 16 & HD & $\mathrm{P}$ & 75 & 50 & 25 & 150 & 50 \\
\hline 17 & SJ & $\mathrm{P}$ & 50 & 50 & 25 & 125 & 41.6 \\
\hline 18 & PI & $\mathrm{L}$ & 50 & 50 & 50 & 150 & 50 \\
\hline 19 & $\mathrm{AL}$ & $\mathrm{L}$ & 50 & 50 & 50 & 150 & 50 \\
\hline 20 & MH & $\mathrm{L}$ & 50 & 25 & 50 & 125 & 41.6 \\
\hline 21 & MP & $\mathrm{L}$ & 25 & 25 & 50 & 100 & 33.3 \\
\hline 22 & SK & $P$ & 25 & 25 & 50 & 100 & 33.3 \\
\hline 23 & LL & $\mathrm{P}$ & 50 & 50 & 50 & 150 & 50 \\
\hline 24 & RS & $\mathrm{P}$ & 50 & 50 & 50 & 150 & 50 \\
\hline 25 & TU & $\mathrm{P}$ & 50 & 50 & 50 & 150 & 50 \\
\hline 26 & ZA & $\mathrm{P}$ & 25 & 50 & 50 & 125 & 41.6 \\
\hline 27 & HI & $\mathrm{P}$ & 50 & 75 & 25 & 150 & 50 \\
\hline 28 & GI & $\mathrm{P}$ & 50 & 50 & 50 & 150 & 50 \\
\hline 29 & PR & $\mathrm{P}$ & 50 & 75 & 50 & 175 & 58.3 \\
\hline 30 & WA & L & 25 & 50 & 25 & 100 & 33.3 \\
\hline \multicolumn{3}{|c|}{ Jumlah \% } & $47.5 \%$ & $50 \%$ & $47.5 \%$ & & $25 \%$ \\
\hline
\end{tabular}


Tabel 3 Hasil Kegiatan Anak Siklus II

\begin{tabular}{|c|c|c|c|c|c|c|c|}
\hline \multirow[b]{2}{*}{ No } & \multicolumn{7}{|c|}{ Koordinasi kecepatan tangan dan kaki } \\
\hline & $\begin{array}{c}\text { Nama } \\
\text { Anak }\end{array}$ & JK & $\begin{array}{c}\text { Melakukan } \\
\text { kegiatan dasar } \\
\text { senam }\end{array}$ & $\begin{array}{c}\text { Melakukan senam } \\
\text { dengan mengikuti } \\
\text { video }\end{array}$ & $\begin{array}{c}\text { Sikap dalam } \\
\text { melakukan } \\
\text { senam }\end{array}$ & Total & $\begin{array}{c}\text { Nilai } \\
\text { rata-rata }\end{array}$ \\
\hline 1 & $\mathrm{AM}$ & $\mathrm{P}$ & 75 & 50 & 100 & 225 & 75 \\
\hline 2 & DS & $\mathrm{P}$ & 75 & 75 & 75 & 225 & 75 \\
\hline 3 & KL & $\mathrm{L}$ & 75 & 75 & 75 & 225 & 75 \\
\hline 4 & MM & $\mathrm{L}$ & 75 & 75 & 75 & 225 & 75 \\
\hline 5 & DS & $\mathrm{P}$ & 75 & 75 & 75 & 225 & 75 \\
\hline 6 & HD & $\mathrm{P}$ & 75 & 75 & 75 & 225 & 75 \\
\hline 7 & $\mathrm{AZ}$ & $\mathrm{P}$ & 75 & 50 & 75 & 200 & 66.6 \\
\hline 8 & AK & $\mathrm{L}$ & 50 & 50 & 75 & 175 & 58.3 \\
\hline 9 & SHN & $\mathrm{P}$ & 50 & 75 & 75 & 200 & 66.6 \\
\hline 10 & AYD & $\mathrm{P}$ & 75 & 75 & 50 & 200 & 66.6 \\
\hline 11 & WH & $\mathrm{P}$ & 75 & 75 & 50 & 200 & 66.6 \\
\hline 12 & ST & $\mathrm{L}$ & 75 & 75 & 50 & 200 & 66.6 \\
\hline 13 & KU & $\mathrm{L}$ & 75 & 75 & 75 & 225 & 75 \\
\hline 14 & LK & $\mathrm{L}$ & 75 & 75 & 100 & 250 & 83.3 \\
\hline 15 & WHA & $\mathrm{L}$ & 50 & 75 & 50 & 175 & 58.3 \\
\hline 16 & HD & $\mathrm{P}$ & 75 & 75 & 50 & 200 & 66.6 \\
\hline 17 & SJ & $\mathrm{P}$ & 75 & 75 & 50 & 200 & 66.6 \\
\hline 18 & PI & $\mathrm{L}$ & 50 & 75 & 75 & 200 & 66.6 \\
\hline 19 & $\mathrm{AL}$ & $\mathrm{L}$ & 50 & 75 & 50 & 175 & 58.3 \\
\hline 20 & $\mathrm{MH}$ & $\mathrm{L}$ & 50 & 25 & 75 & 150 & 50 \\
\hline 21 & $\mathrm{MP}$ & $\mathrm{L}$ & 75 & 75 & 75 & 225 & 75 \\
\hline 22 & SK & $\mathrm{P}$ & 50 & 75 & 75 & 200 & 66.6 \\
\hline 23 & LL & $\mathrm{P}$ & 75 & 50 & 75 & 200 & 66.6 \\
\hline 24 & RS & $\mathrm{P}$ & 75 & 75 & 75 & 225 & 75 \\
\hline 25 & TU & $\mathrm{P}$ & 75 & 75 & 75 & 225 & 75 \\
\hline 26 & $\mathrm{ZA}$ & $\mathrm{P}$ & 50 & 75 & 75 & 200 & 66.6 \\
\hline 27 & HI & $\mathrm{P}$ & 75 & 75 & 50 & 200 & 66.6 \\
\hline 28 & GI & $\mathrm{P}$ & 75 & 75 & 75 & 225 & 75 \\
\hline 29 & PR & $\mathrm{P}$ & 75 & 75 & 100 & 250 & 83.3 \\
\hline 30 & WA & $\mathrm{L}$ & 50 & 75 & 50 & 175 & 58.3 \\
\hline & Jumlah & & $67.5 \%$ & $70 \%$ & $70 \%$ & & $29.2 \%$ \\
\hline
\end{tabular}


Tabel 4 Hasil Kegiatan Anak Siklus III

\begin{tabular}{|c|c|c|c|c|c|c|c|}
\hline \multirow[b]{2}{*}{ No } & \multicolumn{7}{|c|}{ Koordinasi kecepatan tangan dan kaki } \\
\hline & $\begin{array}{c}\text { Nama } \\
\text { Anak }\end{array}$ & JK & $\begin{array}{c}\text { Melakukan } \\
\text { kegiatan dasar } \\
\text { senam }\end{array}$ & $\begin{array}{c}\text { Melakukan senam } \\
\text { dengan mengikuti } \\
\text { video }\end{array}$ & $\begin{array}{l}\text { Sikap dalam } \\
\text { melakukan } \\
\text { senam }\end{array}$ & Total & $\begin{array}{c}\text { Nilai } \\
\text { rata-rata }\end{array}$ \\
\hline 1 & $\mathrm{AM}$ & $\mathrm{P}$ & 100 & 75 & 100 & 275 & 91.6 \\
\hline 2 & DS & $\mathrm{P}$ & 100 & 100 & 100 & 300 & 100 \\
\hline 3 & KL & $\mathrm{L}$ & 100 & 100 & 100 & 300 & 100 \\
\hline 4 & $\mathrm{MM}$ & $\mathrm{L}$ & 100 & 100 & 100 & 300 & 100 \\
\hline 5 & DS & $\mathrm{P}$ & 100 & 100 & 100 & 300 & 100 \\
\hline 6 & $\mathrm{HD}$ & $\mathrm{P}$ & 100 & 100 & 100 & 300 & 100 \\
\hline 7 & $\mathrm{AZ}$ & $\mathrm{P}$ & 100 & 100 & 100 & 300 & 100 \\
\hline 8 & AK & $\mathrm{L}$ & 75 & 100 & 100 & 275 & 91.6 \\
\hline 9 & SHN & $\mathrm{P}$ & 100 & 100 & 100 & 300 & 100 \\
\hline 10 & AYD & $\mathrm{P}$ & 100 & 100 & 100 & 300 & 100 \\
\hline 11 & WH & $\mathrm{P}$ & 100 & 100 & 100 & 300 & 100 \\
\hline 12 & ST & $\mathrm{L}$ & 100 & 100 & 100 & 300 & 100 \\
\hline 13 & KU & $\mathrm{L}$ & 100 & 100 & 100 & 300 & 100 \\
\hline 14 & LK & $\mathrm{L}$ & 100 & 100 & 100 & 300 & 100 \\
\hline 15 & WHA & $\mathrm{L}$ & 75 & 100 & 100 & 275 & 91.6 \\
\hline 16 & HD & $\mathrm{P}$ & 100 & 100 & 100 & 300 & 100 \\
\hline 17 & SJ & $\mathrm{P}$ & 100 & 100 & 100 & 300 & 100 \\
\hline 18 & PI & $\mathrm{L}$ & 100 & 100 & 100 & 300 & 100 \\
\hline 19 & $\mathrm{AL}$ & $\mathrm{L}$ & 100 & 100 & 100 & 300 & 100 \\
\hline 20 & $\mathrm{MH}$ & $\mathrm{L}$ & 100 & 100 & 100 & 300 & 100 \\
\hline 21 & $\mathrm{MP}$ & $\mathrm{L}$ & 100 & 100 & 100 & 300 & 100 \\
\hline 22 & SK & $\mathrm{P}$ & 100 & 100 & 100 & 300 & 100 \\
\hline 23 & LL & $\mathrm{P}$ & 100 & 75 & 100 & 275 & 91.6 \\
\hline 24 & RS & $\mathrm{P}$ & 100 & 100 & 100 & 300 & 100 \\
\hline 25 & TU & $\mathrm{P}$ & 100 & 100 & 100 & 300 & 100 \\
\hline 26 & ZA & $\mathrm{P}$ & 100 & 100 & 100 & 300 & 100 \\
\hline 27 & $\mathrm{HI}$ & $\mathrm{P}$ & 100 & 100 & 100 & 300 & 100 \\
\hline 28 & GI & $\mathrm{P}$ & 100 & 100 & 100 & 300 & 100 \\
\hline 29 & PR & $\mathrm{P}$ & 100 & 100 & 100 & 300 & 100 \\
\hline 30 & WA & $\mathrm{L}$ & 100 & 100 & 75 & 275 & 91.6 \\
\hline & Jumlah & & $98.3 \%$ & $98.3 \%$ & $99.2 \%$ & & $83.3 \%$ \\
\hline
\end{tabular}

